\title{
Prawo naturalne a prawa człowieka: stanowisko Bertholda Walda*
}

DOI: http://dx.doi.org/10.12775/RF.2016.029

\section{Wprowadzenie}

Współcześnie, w codziennej praktyce stosowania prawa konstytucyjnego dominuje pozytywizm prawny ${ }^{1}$. Kierunek ten, ograniczający prawo tylko do treści ustanowionych wolą prawodawcy, opiera się jednak na ograniczonym rozumieniu człowieka jako istoty niezdolnej do głębszego wglądu w rzeczywistość, dostrzega w nim jedynie istotę w sposób aprioryczny kreująca „,sensy”, które mają nią rządzić 2 . Temu przeciwstawia się nurt uznający przenikające struktury bytu ludzkiego prawo naturalne. Pozwala ono odkryć - w zgodności z właściwym rozumieniem

1 Berthold Wald (ur. 1952 r.) to uznany filozof, który uchodzi za najznakomitszego ucznia jednego z najwybitniejszych przedstawicieli tzw. mądrościowej koncepcji filozofii w Niemczech - Josefa Piepera. Wald studiował filozofię, germanistykę, pedagogikę i katolicką teologię we Freiburgu im Breigau oraz w Münster. Od 1986 r., w którym obronił pracę doktorską z filozofii na uniwersytecie w Münster, prowadził zajęcia z tej dziedziny wiedzy na stanowisku adiunkta. Pracę tę kontynuował do 1998 r. W roku 1996 mianowany został profesorem wizytującym na papieskim uniwersytecie w Lateranie. Po uzyskaniu w 2002 r. habilitacji z zakresu filozofii (również na uniwersytecie w Münster) objął katedrę z filozofii systematycznej na filozoficznoteologicznym fakultecie w Paderborn. Od roku 2009 do 2011 pełnił funkcję rektora fakultetu teologicznego na tejże uczelni.

1 B. Wald, Menschen Würde und Menschenrechte, w: Naturrecht und Kirche in säkularen Staat, red. H. G. Niesing, Springer VS, Wiesbaden 2016, s. 53.

2 M. A. Krąpiec, Porzadek prawny - rzeczywistość czy fikcja?, „Człowiek w Kultu-

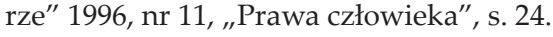


natury ludzkiej - naturalne uprawnienia człowieka (jego prawa w znaczeniu podmiotowym). Związek praw człowieka z prawem naturalnym jest bowiem ewidentny, zważywszy, iż właśnie natura ludzka jest ontyczną bazą dla tychże uprawnień ${ }^{3}$. Niniejsza analiza bezpośrednio dotyka tej właśnie kwestii. Akcentując doniosłość stanowiska wybitnego współczesnego przedstawiciela myśli niemieckiej Bertholda Walda, dokonano tu próby wyjaśnienia, dlaczego temat tabu we współczesnym dyskursie publicznym, czyli prawo naturalne, uznaje on za właściwy fundament dla praw człowieka ${ }^{4}$.

\section{Tendencja do redukowania praw człowieka}

Powszechna Deklaracja Praw Człowieka ONZ wzywająca władzę państwową do przestrzegania tych praw jest bez wątpienia wielkim postępem na drodze do godnego życia w pokoju i wolności. Do wysiłku mającego na celu ochronę praw człowieka poprzez legislację skłoniło Organizację Narodów Zjednoczonych historyczne doświadczenie. Wynika z niego, że nieuznawanie praw człowieka i pogarda wobec nich, przejawiana w aktach barbarzyństwa, stanowią wstrząs dla ludzkich sumień. Wypływa $\mathrm{z}$ tego konstatacja, że w przyszłości nikt nie może być zmuszany do sięgania po ostateczne środki w wyrażaniu swego sprzeciwu wobec tyranii i uciskowi. Deklaracja powstała w odpowiedzi na milionowe mordy dokonane przez nacjonalistyczny reżim niemiecki, jak i zbrodnie popełniane w okresie panowania komunistycznych władz państwowych. Organizacja Narodów Zjednoczonych za pomocą tego dokumentu usiłowała umocnić powszechne przeświadczenie o podstawowych prawach człowieka, jego godności, wartości oraz równouprawnieniu kobiet i mężczyzn, jakkolwiek nie stworzyła w tym zakresie żadnego zobowiązującego prawa międzynarodowego. Niemniej poszanowanie i uznanie przez państwo przyrodzonej godności każdego człowieka, a także jego równych oraz niezbywalnych praw preambuła określa „,jako wspólny standard do osiągnięcia przez wszystkie ludy i wszystkie narody". Wyraża się w niej pragnienie nadania tym zasadom mocy prawej.

Deklaracja nie wspomina o prawie naturalnym i nie wykazuje z nim bezpośredniego związku, jeśli zapisy tego dokumentu przyjąć wprost, bez zwracania uwagi na ich właściwą wymowę. Niemniej bliższe zapo-

3 K. Wroczyński, O źródłach treści praw człowieka, „Człowiek w Kulturze” 1996, nr 11, „Prawa człowieka”, s. 166-167.

4 Autor niniejszego artykułu zakłada, że oddaje zamysł niemieckiego myśliciela, ponieważ upewnił się co do swojej interpretacji w grudniu 2016 r. podczas kilku rozmów z Waldem na temat jego koncepcji.

5 B. Wald, op. cit., s. 53-54. 
znanie się z jego treścią pozwala stwierdzić, iż niewątpliwie inspiruje się on i czerpie swe teoretyczne podstawy z klasycznej myśli na temat prawa naturalnego, przede wszystkim z doktryny Tomasza i jej współczesnych wykładni ${ }^{6}$.

Niestety, w okresie dzielącym dzień ogłoszenia deklaracji od współczesności świadomość nieodzowności uzasadnienia praw człowieka na fundamencie prawa naturalnego niewątpliwie się zmniejszyła. Widoczne jest to obecnie również w obszarze niemieckiego prawa konstytucyjnego. „Prawo naturalne nie wydaje się być przedmiotem zainteresowania współczesnych konstytucjonalistów" - podkreśla Berthold Wald ${ }^{7}$. Jakkolwiek wśród tych prawników nie ma pozytywistów prawa w pełnym tego słowa znaczeniu, to $\mathrm{w}$ ich praktyce stosowania prawa konstytucyjnego, w którym nie wykazuje się troski o filozoficzną kwestię uzasadniania, dominuje jednak pragmatyzm. Poszczególne postanowienia państw członkowskich Unii Europejskiej wskazują na tendencje do łączenia niepodzielności praw człowieka z określonymi, ograniczającymi uwarunkowaniami oraz konsekwentnego wyprowadzania z powszechnych praw człowieka - praw swoistych, na przykład do aborcji i eutanazji. Takie stanowisko uzasadnia się respektem dla godności ludzkiej, ale tę zawęża się do godności osobowej ${ }^{8}$. Oznacza to, że godność „nie przysługuje" wszystkim ludziom, lecz tylko tym o określonych, relewantnych właściwościach osobowych. Stosownie bowiem do współczesnej nauki prawa (Rechtslehre) należy mówić o prawach osoby, a nie człowieka. Tymczasem niepodzielność dotyczy tylko praw człowieka, jako że rozciąga się na wszystkich ludzi bez wyjątku - od początku aż do końca ich życia. Natomiast prawa osoby nie obejmują każdego przedstawiciela gatunku homo sapiens i nie zabezpieczają jego egzystencji od chwili przyjścia na świat do momentu naturalnej śmierci ${ }^{9}$. Dlatego Wald opowiada się za prawami człowieka, a nie określonymi przez dowolnie i bezpodstawnie przyjętą definicję osoby ${ }^{10}$. Nie uwzględnia się bowiem w niej, że akt poczęcia człowieka jest równoznaczny z faktem stania się przez niego bytem osobowym ${ }^{11}$. Tego rodzaju interpretacja przyczynia

6 Taki pogląd podziela B. Wald, o czym autorowi niniejszego artykułu wiadomo po rozmowie $\mathrm{z}$ niemieckim filozofem przeprowadzonej w grudniu $2016 \mathrm{r}$.

7 Ibidem, s. 55.

8 To, czy pojęcie osoby zawęża czy rozszerza zakres obowiązywania praw, zależy od koncepcji antropologicznej (rozumienia pojęcia osoby i człowieka). W personalizmie raczej nie zawęża.

9 B. Wald, op. cit., s. 55.

10 Można również dowolnie i bezpodstawnie przyjąć definicję człowieka.

11 Również dla I. Kanta akt poczęcia istoty obdarowanej wolnością stanowi wydarzenie równoznaczne z przyjściem na świat człowieka jako osoby. Por. I. Kant, Metafizyka moralności, przeł. M Wartenberg, Wydawnictwo Naukowe PWN, Warszawa 1971, s. 113-114. 
się do ograniczania praw człowieka oraz ich pozbawiania, gdyż usprawiedliwia akty aborcji, eutanazji i zapłodnienia in vitro (w następstwie którego uśmierca się nieprzeliczoną liczbę embrionów ludzkich). Prawa człowieka przysługują wszystkim ludziom i dotyczą nie części ich życia, lecz całości.

Deklamatorskie odwoływanie się do idei godności osobowej człowieka budzi podejrzenie, że stanowi zakamuflowaną namiastkę uzasadnienia. $\mathrm{W}$ takim wypadku apele o przestrzeganie praw człowieka faworyzują rozwój legislacji, która znajduje się w niebezpieczeństwie wyemancypowania przyrodzonych praw przysługujących każdemu człowiekowi. Innymi słowy, nie mogłyby one obowiązywać jako dziedzictwo prawa naturalnego.

\section{Kulturowe Hum. tworzenia tabu względem prawa naturalnego i praw człowieka}

Zorientowana na ludzką naturę koncepcja wolności jest dzisiaj wielokrotnie odrzucana jako nieuzasadniona i ograniczona. Wprawdzie nikt nie może sobie poważnie życzyć wolności pozbawionej granic, to jednak jej ograniczenia w pluralistycznym społeczeństwie są akceptowane tylko tam, gdzie służą zachowaniu wolności wszystkich jego członków. Uznanie godności ludzkiej jako podstawowej zasady państwa liberalnej demokracji powinno implikować ochronę autonomii jego obywateli bez określania, co z tego może wynikać dla godnego życia ludzkiego. Również prawa człowieka nie służą ograniczeniu, lecz otwarciu przestrzeni wolności, dopóki w jej sferze nie występuje antagonizm między ludźmi.

Ideał społeczeństwa, który polega na konsensie wszelkich konkretnych wyobrażeń o dobru nie kłóci się oczywiście z koncepcją prawa naturalnego - słusznie podkreśla Wald ${ }^{12}$. Tymczasem, mimo iż prawo to odwołuje się do rozumu (wbrew samowoli autorytetu państwowego), jest odrzucane, ponieważ przyznaje sobie kompetencję rozstrzygania o tym, co jest właściwe. Uznanie godności ludzkiej nie jest już ogniwem łączącym dawne koncepcje prawa naturalnego ze współczesną ideą praw człowieka. Idea godności ludzkiej ograniczająca się do strzeżenia wolności umacnia raczej tendencję do przemilczania czy też marginalizowania (die Tabuisierung) w dyskursie publicznym argumentacji opartej na prawie naturalnym. Kulturowa zamiana prawa naturalnego na prawa człowieka jest nie tylko modyfikacją formy języka, lecz oznacza rezygnację z tejże argumentacji, gdyż uzasadnienie czegokolwiek poza wolnością traktuje się jako niemożliwe. Ta rezygnacja z rozumu na korzyść wolno-

12 B. Wald, op. cit., s. 72. 
ści ma głębokie korzenie i coraz bardziej naznacza współczesność. W obszarze filozofii jest ona uchwytna w idei angielskiego liberalizmu i europejskiego egzystencjalizmu. Wspólne jest im wyobrażenie, że każdy sam może wiedzieć, co jest dla niego dobre; wybrana przezeń tożsamość generuje i określa wszystko - to, kim on jest i co stanowi o jego godności. Konsekwentni libertarianie, których doktrynę opisuje Michael Sandel, zdarzają się jednak rzadko. Wszakże ich idea przewodnia, mówiąca, że każdy przynależy tylko do siebie samego - suponująca zrównanie godności ludzkiej ze zdolnością samostanowienia - oddziałuje z ogromną siłą sugestywną. Ma ona początek w prymitywnym (grobschlächtigen) haśle feminizmu z lat siedemdziesiątych: „Mój brzuch należy do mnie”. Współcześnie ujawnia się $\mathrm{w}$ tendencji do usprawiedliwiania samobójstwa: „Skoro bowiem moje życie należy do mnie, powinienem być wolny do tego, by z niego zrezygnować".

Jednakże ideały wolności współczesnego społeczeństwa są powiązane z problemami, które ostatecznie mogą stać się niebezpieczne dla jego egzystencji. Nie chodzi tu o ogromne zagrożenie z zewnątrz, wynikające z dezorientacji i dekadencji zachodniej cywilizacji, lecz od wewnątrz. Wolność naznaczona dezorientacją rozwija dialektykę, która prowadzi do jej samounicestwienia. Charles Taylor pokazuje to na bazie rozróżnienia Isaiaha Berlina pomiędzy wolnością negatywną i pozytywną oraz ostrzega przed błędem pierwszej z nich, która - jako „czysta koncepcja możliwości" - zmierza do usunięcia przeszkód uniemożliwiających osiągnięcie wolności. Zakłada ona jako oczywistość, że człowiek zna swoje pragnienia i wie, czego chce. Pozytywna wolność natomiast jest określeniem wolności urzeczywistnianej. Uwzględnia tak doniosłe dla wolności uzdolnienia, jak samorozumienie czy pewną zdolność moralnego osądu i samokontroli, ażeby to, czego człowiek chce, nie działo się wbrew jego zasadniczym celom lub samourzeczywistnianiu się. Bez tych uzdolnień może on uchybić wolności, jakkolwiek realizowałby dowolne, własne pragnienia Jednak działając w ten sposób, umacnia tylko swój brak wolności ${ }^{13}$. Nieznajomość swych podstawowych celów prowadzi do samounicestwienia wolności osoby. Jest to jednak pierwszy krok na drodze do dokonującego się niepostrzeżenie kolektywnego zniewolenia. Drugi wynika z rozróżnienia czynu karalnego i grzechu, prawa i moralności, które dla zachodniej cywilizacji naznaczonej przez chrześcijaństwo ma znaczenie zasadnicze. Aktywne społeczeństwo potrzebuje nie tylko praw, lecz również powszechnie uznanych kryteriów moralności. Iluzją jest jednak twierdzenie, że te kryteria tak długo pozostają niezmienione, dopóki większość społeczeństwa dobrowolnie nie przyczyni się do ich zmian. Istnieją bowiem media i siły, które oddziału-

13 Ch. Taylor, Negative Freiheit? Zur Kritik der neuzeitlichen Individualissmus, Surkamp Verlag, Frankfurt am Main 1992, s. 118-172. 
ją spoza większości społeczeństwa, a wpływają na świadomość publiczną. Skutkiem tego od określonego punktu w procesie pogarszania się kryteriów moralności wspólnoty większość nie będzie miała zastrzeżeń do kontynuowania tego procesu.

Niestety, publiczne poszanowanie praw człowieka i jego godności $\mathrm{w}$ imieniu wolności harmonizuje $\mathrm{z}$ niezauważalnym ograniczeniem wolności. Rezygnacja z prawdy na rzecz wolności de facto powoduje zniewolenie. O doniosłości uzasadnień dokonywanych na mocy prawa naturalnego świadczy to, że odwołanie się do jego kryteriów stwarza możliwość dostrzeżenia niezauważanego braku wolności. Konieczne jest przeforsowanie tych kryteriów, dopóki istnieje jeszcze taka możliwość - słusznie akcentuje Wald ${ }^{14}$.

\section{Nieodzowność prawa naturalnego jako fundamentu idei praw człowieka}

Prawo naturalne nie wynika z woli człowieka - prawodawcy, nie jest także za jego przyczyną wprowadzane w życie ${ }^{15}$. Oznacza ono po prostu uznanie Boskiego Prawodawcy; ma boską naturę. Niestety, ta koncepcja znajduje coraz mniej zwolenników. Niemniej, według niemieckiego myśliciela, nadal spotyka się prawników i polityków wychodzących poza pragmatyczny punkt widzenia, zainteresowanych ostatecznym uzasadnieniem norm prawnych, czyli otwartych na prawo naturalne. Dla Walda całkowicie bezpodstawne jest przeświadczenie, artykułowane przez niektórych prawników i polityków, zgodnie z którym zasad prawa naturalnego w prawodawstwie uwzględniać nie trzeba, ponieważ istnieje wiele stosownych dokumentów chroniących fundamentalne uprawnienia ludzi (m.in. Powszechna Deklaracja Praw Człowieka, Europejska Konwencja Praw Człowieka). Mniemanie, że będą one obowiązywać długo bez właściwego uzasadnienia, czyli z pominięciem prawa naturalnego, należy uznać za coś więcej niż zwykłą naiwność. Zaniechanie tej argumentacji to po prostu oszukiwanie siebie. Jeżeli nauka o prawie naturalnym nie zostanie zachowana jako punkt odniesienia - to tym samym prawa człowieka coraz częściej będą ustalane jedynie wskutek decyzji parlamentów. W rezultacie, wtedy również w obliczu prawa określona kategoria osób pozbawiana będzie życia (np. w aktach aborcji i eutana-

14 B. Wald, op. cit., s. 74.

15 Naturalnie, prawo naturalne musi być jakoś zapisane, skodyfikowane i wtedy jest wprowadzane w życie przez człowieka. Tu mogą się ujawnić również różnice $\mathrm{w}$ interpretacji. 
zji), ponieważ w kwestii ich dalszego istnienia wolno za nie podejmować decyzje $^{16}$. Na gruncie nauki o prawie naturalnym jest to niemożliwe.

Znawcy przedmiotu twierdza, że cały katalog podstawowych praw w niemieckiej konstytucji tworzą pozytywne, uchwalone konstrukcje prawne. Każde z tych praw może zostać zmienione, ze względu na to, że nie jest akceptowane uzasadnienie odwołujące się do norm prawa naturalnego. Na tej samej zasadzie, według prawników, można zawsze zakwestionować ich ważność ${ }^{17}$. Tak rzeczywiście się dzieje. W parlamentach europejskich uchwala się prawa promujące indywidualizm i przyczyniające się do niszczenia wspólnoty rodzinnej (m.in. przez przyjęcie homoseksualizmu jako prawa człowieka). Nasila się tendencja do utraty przez prawa człowieka ich funkcji ochronnej. Określenie "prawo człowieka do aborcji i eutanazji" jest sprzeczne samo w sobie. Z punktu widzenia norm prawa naturalnego tego rodzaju uprawnienia są wykluczone. Prawo zezwalające na zabijanie niewinnych i bezbronnych ludzi jest wypaczone, zdeformowane. Prawo, które w sensie źródłowym powinno służyć ochronie człowieka, stanowi śmiertelne zagrożenie, gdy zostaje zamienione w swe przeciwieństwo.

Jednocześnie przybierają na sile apele o zachowanie praw człowieka. Jednak gdy prawo naturalne nie jest akceptowane, wówczas hasła te są czystą retoryką ${ }^{18}$. Należy zatem powrócić na płaszczyznę warunkującą możliwość uzasadnienia praw człowieka, czyli prawo naturalne. Dlatego trzeba, podkreśla Wald, przypominać, naświetlać i na nowo formułować naukę o nim. Nie może ona być zapomniana: przeciwnie musi zostać zachowana, jeśli fundament praw człowieka ma się nie zachwiać ${ }^{19}$.

\section{Dlaczego koncepcja prawa naturalnego Tomasza z Akwinu może być podstawa idei praw człowieka?}

Zanim Wald udzieli wprost wyjaśnienia tytułowej kwestii, konstatuje trudności z opowiedzeniem się za prawem naturalnym, jakie współcześnie dochodzą do głosu, wynikające m.in. stąd, że nie istnieje jedna, powszechnie przyjęta jego interpretacja. Możliwe jest bowiem rozróżnienie przynajmniej trzech zasadniczych teorii tego rodzaju prawa: oświeceniowo-indywidualistyczna, racjonalistyczna i metafizyczna. Wszystkie

16 B. Wald, op. cit., s. 55-57.

17 Czymś innym jest natomiast korekta interpretacji norm, która jest możliwa również $\mathrm{w}$ odniesieniu do norm prawa naturalnego.

18 B. Wald, op. cit., s. 53.

19 Rozmowa z Waldem w grudniu 2016 r. 
te historyczne interpretacje prawa naturalnego spotykają się z zarzutami ze strony pozytywizmu prawnego ${ }^{20} \mathrm{i}$ dla tego nurtu nie brzmią przekonująco. Według słusznego przeświadczenia niemieckiego myśliciela, zastrzeżenia nieprzypadkowo pojawiły się w odniesieniu do dwóch pierwszych teorii, czyli oświeceniowej i racjonalistycznej. Całkiem inaczej bowiem trzeba tu postrzegać propozycję metafizyczno-antropologiczną Tomasza - słusznie konstatuje Wald ${ }^{21}$.

Przypisywana Gottfriedowi W. Leibnizowi racjonalistyczna koncepcja prawa naturalnego, w której przez dedukcję usiłuje się wywieść $\mathrm{z}$ uniwersalnych jego zasad cały porządek prawny, pozbawiła pozytywne prawo samodzielnej legitymacji. Nastąpiło nadmierne poszerzenie prawa naturalnego ${ }^{22}$, które uczyniło zbytecznym rozróżnienie pomiędzy nim a prawem pozytywnym. Paradoksalnie stało się to także pretekstem do podważenia prawomocności prawa naturalnego ${ }^{23}$.

Antymetafizyczna, opierająca się na autonomii indywiduum oświeceniowa koncepcja prawa naturalnego Thomasa Hobbesa ujawnia niedoskonałość odmiennego rodzaju, a mianowicie zawężenie wizji tegoż prawa. Angielski filozof redukował ludzką naturę do jej określonej, negatywnej strony przejawiającej się $\mathrm{w}$ agresywnych tendencjach wobec innych osób. Naturalne ukierunkowanie człowieka na więź wspólnotową zostało więc przez niego postawione pod znakiem zapytania. Hobbes reprezentował pod tym względem stanowisko antymetafizyczne, gdyż wykreował wizję człowieka na podstawie jego faktycznych zachowań, a nie jego natury i istoty. Obserwacja wzajemnych odniesień ludzi zbyt naznaczonych wrogością i konfliktami wystarczyła temu filozofowi podkreśla Wald - aby uznać za fikcję arystotelesowski obraz, zgodnie z którym ze swej istoty dążą oni do życia we wspólnocie.

Według Walda, stworzona przez Tomasza z Akwinu metafizyczno-antropologiczna wizja prawa naturalnego wychodzi naprzeciw trudnościom związanym z jego postrzeganiem jako fundamentu praw człowieka. Doktor Anielski w swym rozumieniu człowieka koncentruje się

20 Pozytywizm prawny, najogólniej biorąc, określa prawo jako wyraz woli suwerena. Oznacza to, że stanowi ono skutek posiadania władzy umożliwiającej nieskrępowane tworzenie prawa. Tak rozumiane pozostaje prawem niezależnie od tego, czy jest moralne (sprawiedliwe). Por. H. Jakuszko, Krytyka oświeceniowych koncepcji prawa naturalnego, „Zadania Współczesnej Metafizyki” nr 8, Substancja. Natura. Prawo naturalne, Polskie Towarzystwo Tomasza z Akwinu, Lublin 2006, s. 308-309.

${ }^{21}$ B. Wald, op. cit., s. 64-65.

22 Rzeczywiście nie do zaakceptowania jest nadmierne poszerzenie - poprzez dedukcję - tego, do czego jest uprawnione prawo naturalne. Istnieje cały obszar, o którym traktuje nauka prawa, podlegający cnocie roztropności. Ujawnia się on w momencie pierwszego spotkania człowieka z konkretną sytuacją wymagającą działania, domagającą się rozstrzygnięcia poprzez osąd moralny rozumu. Nie sposób bowiem w tym wypadku uzyskać rozwiązanie metodą dedukcji.

23 Ibidem, s. 64. 
na tym, do czego naprawdę dąży on w zgodzie ze swoją naturą ${ }^{24}$. Ten uniwersalny myśliciel przeprowadził swe analizy, dokonując wglądu $\mathrm{w}$ istotę człowieka, a nie na podstawie zaobserwowanych empirycznie zachowań. Na tych ostatnich bazował Hobbes ${ }^{25}$.

Tomaszowej wizji nie można traktować tylko jako projekt interesujący w aspekcie historycznym. Jej autor nie dowodzi prawdziwości tez, opierając się na uznanej tradycji, myśli Arystotelesa czy Cycerona, którą usiłuje rozwinąć. Argumentuje oryginalnie, bowiem nie tylko rozumowo, na podstawie samej rzeczy- jej cech immanentnych. Odwołuje się on także do ludzkiego doświadczania samego siebie, które jest (a przynajmniej może się stać) udziałem każdego ${ }^{26}$. Jest ono naturalnym, spontanicznym, bezpośrednim poznawaniem siebie jako podmiotu trzech naturalnych inklinacji, a mianowicie: do zachowania własnego życia (pierwsza), jego przedłużenia (druga) oraz poszukiwania prawdy i dążenia do pokojowej egzystencji w społeczeństwie (trzecia) ${ }^{27}$.

Na podstawie doświadczenia możliwe jest wyjaśnienie, na przykład, czego ze swej natury ludzie chca, na jakich dobrach im zależy. Pod względem oczekiwań natura ludzka w kwestiach zasadniczych się nie zmieniła: wszyscy pragną żyć i są zatroskani o swą egzystencję, chcą posiadać własność, założyć rodzinę, nawiązywać przyjazne relacje, poznać prawdę, czcić Boga. Konsekwentnie jako wielką niesprawiedliwość odczytują uniemożliwianie czy też utrudnianie urzeczywistniania tych naturalnych dążeń.

Prawo naturalne $\mathrm{w}$ formie przedstawionej przez Tomasza $\mathrm{z}$ Akwinu ma zatem rzeczywiście potencjał umożliwiający uzasadnienie niepodzielności praw człowieka bez konieczności nadmiernego ich rozszerzania (Leibniz) czy zawężania (Hobbes). Tomaszowe rozumienie ludzkiej natury, stosownie do swego aspektu materialnego ${ }^{28}$ również

24 Jednym z charakterystycznych dążeń człowieka (wynikającym z jego istoty), niezależnie od tego czy działa on moralnie dobrze, czy źle, jest to, że orientuje się na istnienie we wspólnocie.

25 B. Wald, op. cit., s. 65-66.

26 Według Walda, o doświadczaniu siebie samego Tomasz wypowiada się m.in. w dziele Die unitate intellectus contra Averroistas.

27 Nie każdy człowiek dokonuje refleksji nad tego rodzaju doświadczeniem, ale zdaniem Walda - każdy może je mieć. Sprzyja temu odpowiednia sytuacja. Na przykład, jeżeli ktoś zostanie niesłusznie skazany na pobyt w więzieniu, to tę krzywdę postrzega jako niesprawiedliwość.

28 Można dokonać rozróżnienia pomiędzy formalnym i materialnym aspektem prawa naturalnego. Formalny obejmuje elementarne zasady, np. tę, że każdemu należy oddać to co mu się należy i nikomu nie wolno czynić krzywdy. Materialny aspekt zakłada treściową konkretyzację tych zasad. Wyjaśnia, co znaczy nie czynić niesprawiedliwości względem drugiego człowieka i odpowiada, iż równoznaczne jest niepopełnianie zabójstw, nieoszukiwanie, niemówienie publicznie tego, co może zaszkodzić dobremu imieniu. 
w kontekście naturalistycznego pojęcia natury - jest przekonujące. Naturalizm zakłada, że nie da się poznać zasady, według której naturalny porządek jest normatywizowany (a nawet skłania się ku tezie, iż nie istnieje normatywność stawiająca granice ludzkiej samowoli). Za kluczowe należy uznać doświadczanie samego siebie przez człowieka. Prawdziwość prawa naturalnego ma swój fundament przede wszystkim w tego typu doświadczeniu i przez nie się weryfikuje ${ }^{29}$. Jest ono bowiem nie tylko źródłem wiedzy o ludzkiej naturze, lecz również o przysługujących ludziom określonych uprawnieniach. Wiedza o własnej naturze, z racji bezpośredniego jej związku z doświadczeniem siebie samego przez człowieka, istotnie odróżnia się od informacji zapośredniczonych kulturowo; ma uniwersalnym charakter, który uprawnia do przeprowadzania krytyki każdego typu porządków prawnych ${ }^{30}$.

\section{Racjonalny charakter prawa}

Wolność wyboru i wolność działania nigdy nie są absolutne i dlatego należy ustalić kierunek, w którym powinniśmy działać. Pomoc na tym polu świadczą człowiekowi moralność i prawo, okazujące się niejako kompasami ludzkiego postępowania. Moralność oddziałuje na przeświadczenia ludzi w perspektywie wewnętrznej jako głos sumienia, a prawo różni się od niej dwiema cechami. Po pierwsze, jego przedmiotem nie jest moralne dobro $w$ każdym aspekcie, lecz również sprawiedliwośćc ${ }^{11}$ gdyż działanie człowieka dotyczy nie tylko jego samego, lecz także innych ludzi. Po drugie, prawo stanowi środek przymusu nie tylko wewnętrznego, lecz przede wszystkim zewnętrznego. Brak poszanowania i przekraczanie prawa muszą być zwalczane, ażeby chronić jego autorytet.

Pomimo przymusowego charakteru porządku prawnego, jego źródłem nie jest - według Tomasza - wola, lecz rozum. Prawo bowiem, podobnie jak rozum, stanowi regułę oraz miarę ludzkich działań i jest zależne od rozumu, a nie woli ${ }^{32}$. Gdyby wola była źródłem porządku

29 B. Wald, op. cit., s. 57-58.

30 B. Wald, Natura i prawo naturalne - perspektywa historyczna, "Zadania Współczesnej Metafizyki", op. cit, s. 74 .

31 Sprawiedliwość też jest moralnym dobrem, a jednocześnie ma znaczenie kluczowe jako regulator relacji międzyludzkich.

32 Owszem, u Tomasza rozum stanowi porządek prawny. „Normą, miarą [...] pierwszym początkiem ludzkich postępków jest rozum" - podkreśla Doktor Anielski. Por. Św. Tomasz z Akwinu, Suma teologiczna, t. 13, Prawo, kwestia 90, art. 1, tłum. i obj. o. P. Bełch,, Katolicki Ośrodek Wydawniczy „Veritas”, Londyn 1986, s. 10. Jednocześnie nie znaczy to, aby wola nie mogła mieć udziału w działaniu o charakterze prawa, jeżeli tylko jest normowana przez rozum. Por. ibidem, s. 11. 
prawnego, byłby on sprawiedliwy przez to, że jest chciany i postanowiony przez prawodawcę. Z samej definicji prawa wynika, że wówczas niesprawiedliwe prawa nie mogłyby istnieć. Tymczasem te ustalone przez ludzi są sprawiedliwe lub nie. Sprawiedliwe mają moc wiążącą sumienie; $w$ przeciwnym wypadku nie są prawami, lecz środkami przemocy.

Człowiek czy organ, który jest uprawniony do wydawania rozporządzeń prawnych z myślą o dobru wszystkich ludzi, pozostaje w zgodzie z celem prawa tylko wówczas, gdy zapewnia racjonalne normowanie działania. Sprawiedliwość i wzgląd na dobro wspólne powinny być nieodzownymi cechami praw państwowych, jeśli chcą one być trwale otaczane należytym respektem.

Wszystkie rodzaje prawa (boskiego lub ludzkiego, naturalnego albo pozytywnego) wiąże fakt, że ich cel zależy przede wszystkim od rozu$\mathrm{mu}$, a od woli tylko tyle, o ile motywuje ona rozum do ich percepcji i uznaje rezultat tej percepcji. Dlatego w definicję prawa, zgodnie z myślą Tomasza, nie jest wpisana ani wola, ani władza, lecz tylko prawowity autorytet ${ }^{33}$. „Prawo jest niczym innym, niż rozporządzeniem rozumu z uwagi na dobro wspólne, wydanym i publicznie ogłoszonym przez tego, kto sprawuje pieczę nad wspólnotą" ${ }^{34}$. Zasadniczy związek tej charakterystyki z rozumem nie jest powszechnie akceptowany. Wystarczy wspomnieć tu pogląd Dunsa Szkota i skrajnie odmienną argumentację Thomasa Hobbesa, który utrzymuje, że nie prawda określa prawo, lecz autorytet.

\section{Konkretyzacja praw czlowieka na podstawie prawa naturalnego}

Wynikająca z natury zasadnicza przesłanka prawa i moralności: czyń dobro i unikaj zła, jest kompasem, który wskazuje człowiekowi kierunek postępowania, nie informując bliżej o tym, czym jest dobro. Dlatego powstaje pytanie, czy człowiek obdarzony jest naturalną pewnością, co jemu i innym przysługuje, czyli ma status uprawnienia. Punktem wyjścia w poszukiwaniu odpowiedzi jest tutaj także odwołanie się do doświadczania siebie samego, gdyż ono pozwala te uprawnienia (prawa przysługujące każdemu człowiekowi) zrozumieć. Wszystko, do czego ze swej natury człowiek wykazuje skłonność, rozum pojmuje jako dobro i elementarny cel ludzkiego działania - słusznie podkreśla Wald ${ }^{35}$. Termin lex naturalis należy interpretować $\mathrm{w}$ dwóch aspektach: jako treść prawa stosowną do ludzkiej natury oraz sposób, w jaki poznajemy tę

33 B. Wald, Menschen ..., op. cit., s. 67.

${ }_{34}$ Św. Tomasz z Akwinu, Suma teologiczna, t. 13, Prawo, kwestia 90, art. 4, s. 16.

35 B. Wald, Menschen ..., op. cit., s. 67. 
treść - właśnie z natury, a nie wskutek cudzego pouczenia lub za pomocą prawa państwowego.

Bezpośrednio z natury człowieka pochodzi jego wiedza o elementarnych uwarunkowaniach zachowania i rozwoju własnej egzystencji, skłaniająca do tego, by działać stosownie do podstawowych inklinacji, czyli np. chronić swoje życie i funkcjonować we wspólnocie, założyć rodzinę czy poznawać prawdę - szczególnie o Bogu. Każdy wie bez pouczenia, że drugiemu człowiekowi na jego egzystencji tak samo zależy, jak i na własnej.

Jak celnie konstatuje Wald, z teleologicznej struktury dążeń ludzkich realizowanych w działaniu Tomasz uzyskał kryteria, z którymi musi się zmierzyć każdy konkretny porządek prawny. Przy tym najbardziej oczywiste są obowiązki zaniechania: zakaz zabijania niewinnych, stosowania przemocy $\mathrm{w}$ małżeństwie i rodzinie, tłumienia naturalnej skłonności poszukiwania prawdy i Boga. Każdy człowiek ma bowiem naturalne - a nie nadane przez państwo - prawa, między innymi: do życia, zawarcia małżeństwa, zrodzenia potomstwa, poszukiwania prawdy i czczenia Boga. Zatem ochrona przez państwo praw przyrodzonych jest nieodzowna, mimo iż pociąga za sobą pewne koszty.

Ograniczenie prawa do wolności jest słusznie postrzegane jako bardziej znaczące aniżeli ograniczenie praw socjalnych. To, które prawa należy zagwarantować, pozostaje - w odróżnieniu od elementarnych praw wolności - mniej oczywiste i historycznie kontyngentne, ale jednak dostępne poprzez racjonalny namysł. Przykładowo, prawo do życia nie może zostać zabezpieczone bez zagwarantowania obywatelowi praw socjalnych - do wykształcenia, zarobkowania oraz co najmniej minimum egzystencji, do bezpłatnej opieki medycznej i umożliwiającego utrzymanie się wsparcia materialnego ze strony państwa. Prawo do życia z wyłączeniem elementarnych praw socjalnych byłoby wyrazem cynizmu.

Znalezienie właściwego znaczenia (Ausbuchstabierung) prawa naturalnego wymaga umiejętności odniesienia oczywistych zasad tego prawa do ludzkiego doświadczenia w konkretnej historycznej sytuacji. Wald zauważa, iż przy określaniu poszczególnych praw na podstawie ich relacji do prawa naturalnego, Tomasz zwrócił uwagę na kwestie metodyczne (Vefahrensfragen), a analizowane treści przedstawił w sposób zwięzły ${ }^{36}$. To pokazuje się $\mathrm{w}$ jego rozważaniach na temat relacji praw narodów oraz obywatelskiego do prawa naturalnego. Najpierw podkreślił: „,(...) każdą rzecz można zasadniczo podzielić według tego, co należy do jej istoty" ${ }^{\prime 37}$. Konsekwentnie - do istoty prawa ludzkiego należy to,

36 Ibidem, s. 68.

37 Św. Tomasz z Akwinu, Suma teologiczna, t. 13, Prawo, kwestia 95, art. 4, tłum. i obj. o. P. Bełch, Katolicki Ośrodek Wydawniczy Veritas, Londyn 1986, s. 74. 
że wywodzi się ono z prawa natury. Również zgodnie z tą zasada, zdaniem Tomasza, prawo pozytywne dzieli się na prawo narodów i obywatelskie. Pierwsze z nich wyprowadził on z prawa naturalnego, tak jak konkluzje wynikające z zasad ${ }^{38}$, a drugie poprzez uszczegółowienie (per modum particularis determinationis). Każde państwo bowiem na gruncie tego prawa powinno bliżej określać odpowiednie dla dobra wspólnego zalecenia normatywne. Wszelkie prawo, które nie potrafi zadośćuczynić temu dobru i zasadzie sprawiedliwości pozostaje na zewnątrz prawa naturalnego. Jednak nie każde prawo jest $\mathrm{w}$ ten sam sposób, raz na zawsze, wyprowadzone z prawa naturalnego. Natomiast stwarzanie odpowiedniej sytuacji prawnej i ciągłe (wciąż na nowo) dopasowywanie jej do zmieniających się okoliczności wymaga doświadczenia i zdolności oceny - konkluduje Wald ${ }^{39}$.

\section{Doświadczenie siebie jako źródło poznania uprawnień w kontekście problematyki pryncypiów}

Rozumny charakter prawa umożliwia obywatelom, jak i reprezentantom władzy państwowej porozumienie w odniesieniu do pryncypiów oraz treści tego prawa. Powstaje pytanie skąd rozum czerpie wiedzę umożliwiającą uzyskanie świadomości symetrii ${ }^{40}$. Otóż jest ona w zasadzie dostępna dla każdego człowieka w sposób naturalny, bez konieczności uczenia się i odrębnego uzasadnienia.

W obszarze praktycznego poznania (w odniesieniu do tego, co być powinno) wszelka wiedza dotyczy dobra będącego celem działania i doń pobudzającego. Podobnie jak człowiek spontanicznie zauważa jakiekolwiek istnienie, również samoistnie dostrzega, iż wszelkieżywe stworzenia są ukierunkowane na to, co dobre (życia nie sposób zrozumieć inaczej) ${ }^{41}$. Dobro jest tym, do czego wszyscy dążą: Bonum est quod omnia appetunt ${ }^{42}$.

38 Na przykład, z prawa natury wynika prawo sprawiedliwego kupna, sprzedaży itp., które potrzebne jest człowiekowi do funkcjonowania we wspólnocie. Z natury bowiem człowiek jest stworzeniem społecznym. Por. ibidem.

39 B. Wald, Menschen ..., op. cit., s. 67.

40 Pierwszym wyrazem teoretycznego poznania jest zainteresowanie samym faktem istnienia rzeczy, a podstawą wszelkiego postępu w zakresie tego poznania jest zasada niesprzeczności. (Nie można czegoś jednocześnie afirmować i negować). Podstawę tej zasady, na której bazują kolejne, stanowi to, co rozumie się przez pojęcia bytu i niebytu.

41 Również dla brytyjskiej filozofki Phillipy Foot określenie "dobry” odnosi się bez wyjątku do świata bytów żyjących. Por. Ph. Foot, Die Natur des Guten, Surkamp Verlag, Frankfurt am Main 2004, s. 12.

${ }_{42}$ Teza ta może zabrzmieć cynicznie, ale jedynie w ustach tego, kto sam coś uznał za dobro, mimo iż nie tylko nie jest ono nim, ale wręcz jego przeciwieństwem. 
Zdaniem Walda, właściwa trudność polega na zrozumieniu związku pomiędzy bezpośrednio dostrzegana, celowościową strukturą bytu żywego i zasadą lex naturalis praktycznego rozumu głosząca, że dobro należy czynić i dążyć do niego, a zła unikać. Na jakiej podstawie może być wywiedziona z teleologicznej wypowiedzi o bycie - mającej charakter twierdzenia (wszelka istota żywa jest ukierunkowana na dobro) teza o tym, co być powinno: czyń dobro a unikaj zła? Wiedza o moralnym zobowiązaniu wobec dobra nie jest jednak wyprowadzona $\mathrm{z}$ jego teleologicznego charakteru, lecz wynika z doświadczania siebie samego przez człowieka. Ludzie przecież bezpośrednio rozpoznają swoje inklinacje $\mathrm{w}$ zachowaniu drugiej istoty żyjącej. Na przykład, znają uczucie pragnienia i dlatego rozumieją zachowanie zwierzęcia łaknącego wody. Stwierdzenie u niego pragnienia implikuje konstatację, że realizacja tej potrzeby musi być dla zwierzęcia dobra i znacząca, jak dla człowieka. Wszelkie żywe stworzenia ujawniają tego rodzaju zachowania, ponieważ ich ukształtowane przez naturę cele nie mogą im być obojętne.

Nie ulega więc wątpliwości, jak należy rozumieć pryncypium: czyń dobro i unikaj zła. Ponieważ człowiek ma zdolność empatii, dlatego bezpośrednio rozpoznaje (jeżeli jest rzetelny), iż przeszkadzanie mu w realizacji celów, które mają dla niego w życiu znaczenie elementarne jest samowolne i nieuczciwe. Również ograniczanie praw innych osób słusznie postrzegane jest jako niesprawiedliwość, a czynienie dobra i unikanie zła uważane jest za oczywisty obowiązek. Okazuje się to ewidentne nie tylko w wyniku logicznego rozumowania, lecz za sprawą wiedzy o ludzkim jestestwie (bycie) uzyskiwanej w bezpośrednim doświadczaniu siebie samego.

\section{Godność osobowa i prawa człowieka}

Godność ludzka i prawa człowieka ściśle się ze sobą łączą: prawa te przynależą do człowieka, ponieważ jest on osobą ${ }^{43}$. Pojęcie godności zostało wprowadzone na stałe do konstytucji różnych państw, ale niestety stało się zasadą prawną obowiązująca, zdaniem niemieckiego myśliciela, poniekąd tylko ze względu na fakt, że tak postanowił parlament, a nie dlatego, iż ma ono swój fundament w naturze człowieka. W konsekwencji prawa człowieka ostatecznie stają się zależne od sytuacji kulturowej, a ich wartość zmienia się wraz z upływem czasu, stosownie do decyzji parlamentarnych.

Według słusznego stwierdzenia Walda, nie bez zastrzeżeń należy odnosić się do współczesnych orzeczeń i opinii (w formie uchwał, jak i wypowiedzi niektórych filozofów oraz prawników) na temat godno-

43 B. Wald, Menschen..., op. cit., s. 66. 
ści ludzkiej między innymi dlatego, że nie definiuje się jasno tego pojęcia. Ten brak przejrzystości zauważa niemiecki myśliciel również przy próbie formułowania odpowiedzi na pytanie, dlaczego godność ta jest podstawą praw człowieka. Z punktu widzenia myśli klasycznej nie do przyjęcia jest pogląd zainspirowany przez Locke'a, do którego nawiązuje współczesne prawodawstwo konstytucyjne, m.in. niektórych państw Unii Europejskiej. Redukuje się bowiem w nim to pojęcie do tzw. godności osobowej, właściwej tylko ludziom aktualnie zdolnym do ustosunkowania się względem siebie (posiadających samoświadomość i pamięć). Przy takim jednak rozumieniu godności nie można wskazać podstawy praw człowieka w odniesieniu do wszystkich, lecz tylko do ludzi dysponujących określonymi przymiotami osobowymi. Istnieje jednak, zgodnie z ujęciem zarówno Tomasza z Akwinu, jak i Kanta, imperatyw nakazujący mówić o prawach przysługujących każdemu człowiekowi bez wyjątku od chwili jego poczęcia do momentu śmierci. Ich podstawę stanowi godność człowieka, która swe źródło znajduje w naturze ludzkiej (istocie człowieka); przysługuje każdemu wyłącznie dlatego, iż wszyscy już od momentu zaistnienia są osobami ludzkimi, a nie dlatego, że aktualnie mają określone cechy.

Godność wyróżnia człowieka spośród wszystkich innych istot, ale jednocześnie stanowi dlań zadanie - wynikają z niej określone, wzajemne zobowiązania wobec pozostałych ludzi, zwłaszcza powinność uznawania ich podstawowych praw.

Kwestia godności osoby ludzkiej i związana z nią problematyka praw człowieka nie ma zatem charakteru abstrakcyjnego. Dlatego, że natura ludzka jest racjonalna, jawi się ona jako najgodniejsza ze wszystkich natur. Na długo, zanim Kant przedstawił swą teorię - dzięki której odróżnienie godności od wartości stało się jednym z często dyskutowanych tematów w dziedzinie praw osoby - Tomasz postrzegał te kwestie podobnie. Godność posiada byt istniejący ze względu na siebie samego (tzn. jest samoświadomy, decyduje o sobie, jest rozumny i wolny). Znakiem tego, że istnieje on w ten sposób jest wolność. Dzięki swej racjonalnej naturze człowiek ma władzę nad swym postępowaniem i jest źródłem swego działania. Inne istoty żywe kierują się skłonnościami i instynktem. Człowiek zaś realizuje cele (uprzednio poznaje je i dobrowolnie wybiera), gdy w odpowiedni sposób prowadzi życie. Natura i wolność nie są przeciwieństwami, lecz elementami komplementarnymi. Bez świadomego posługiwania się wolnością nie można osiągnąć celów, na które natura jest ukierunkowana ${ }^{44}$. Dlatego Tomasz mógł powiedzieć, że wolność musi być zjawiskiem wewnętrznym w stosunku do popędu ${ }^{45}$.

44 Ibidem, s. 69.

45 Tomasz z Akwinu słusznie podkreślił, że wiele dóbr znikłoby, gdyby nie istniała wolność woli (np. przekreślona byłaby możliwość osiągnięcia cnoty, otrzyma- 
Respektować godność człowieka oznacza również respektować ludzką wolność. Nikt nie ma prawa dowolnego ingerowania w życie drugiej osoby, dlatego że postępuje ona zgodnie ze swą naturą. Godność ludzka suponuje, iż żaden człowiek nie może być potraktowany przedmiotowo, gdyż istnieje ze względu na siebie samego, czyli realizuje swe człowieczeństwo wtedy, gdy w wolności determinuje sam siebie. Na tę wolność nikt nie powinien bezprawnie oddziaływać z zewnątrz. Prawa człowieka obejmują obszary, których nikomu nie wolno naruszać ${ }^{46}$.

\section{Bibliografia}

Foot Ph., Die Natur des Guten, Surkamp Verlag, Frankfurt am Main 2004.

Jakuszko H., Krytyka oświeceniowych koncepcji prawa naturalnego, „Zadania Współczesnej Metafizyki”, nr 8, Substancja. Natura. Prawo naturalne, red. nauk. A. Maryniarczyk, Polskie Towarzystwo Tomasza z Akwinu, Lublin 2006.

Kant I., Metafizyka moralności, przeł. M Wartenberg, Wydawnictwo Naukowe PWN, Warszawa 1971.

Krąpiec M.A., Porzadek prawny - rzeczywistość czy fikcja?, „Człowiek w Kulturze" 1996, nr 11.

Taylor Ch., Negative Freiheit? Zur Kritik der neuzeitlichen Individualissmus, Surkamp Verlag, Frankfurt am Main 1992.

Tomasz z Akwinu, Suma teologiczna, t. 13, Prawo, kwestia 95, art. 4, tłum. i obj. o. P. Bełch,, Katolicki Ośrodek Wydawniczy „Veritas”, Londyn 1986.

Tomasz z Akwinu, Summa contra gentiles. Prawda wiary chrześcijańskiej, ks. 3, przeł. Z. Włodek, W. Zega, Wydawnictwo „W Drodze”, Poznań 2007.

Wald B., Menschen Würde und Menschenrechte, w: Naturrecht und Kirche in säkularen Staat, red. H.G. Niesing, Springer VS, Wiesbaden 2016.

Wald B., Natura i prawo naturalne - perspektywa historyczna, „Zadania Współczesnej Metafizyki", nr 8, Substancja. Natura. Prawo naturalne, Polskie Towarzystwo Tomasza z Akwinu, Lublin 2006.

Wald B., Bład antropologiczny i jego konsekwencje we wspótczesnej filozofii, „Zadania Współczesnej Metafizyki", nr 5, red. nauk. A. Maryniarczyk, Polskie Towarzystwo Tomasza z Akwinu, Lublin 2003.

Wald B., Substantialität und Personalität, Mentis Verlag, Paderborn 2005.

Wroczyński K, O źródłach treści praw człowieka, „Człowiek w Kulturze” 1996, nr 11.

nia sprawiedliwej nagrody i kary, kierowania się rozwagą). Por. Św. Tomasz z Akwinu, Summa contra gentiles. Prawda wiary chrześsijańskiej, ks. 3, tłum. Z. Włodek, W. Zega, Wydawnictwo „W Drodze”, Poznań 2007, s. 201-211.

46 B. Wald, Menschen..., op. cit., s. 69. 


\section{Streszczenie}

\section{Prawo naturalne a prawa człowieka: stanowisko Bertholda Walda}

\section{Słowa kluczowe}

filozofia; prawo naturalne; prawa człowieka; osoba; godność ludzka; Tomasz z Akwinu; Berthold Wald

W artykule przedstawiono poglądy Bertholda Walda w kwestii podstaw praw człowieka. Autor artykułu podziela poglądy niemieckiego myśliciela, że fundamentem tych praw jest prawo naturalne, co w kulturze współczesnej bywa pomijane, przyczyniając się do błędów w pojmowaniu godności i wolności człowieka. Wald, zdaniem autora, w oryginalny sposób pokazuje racjonalny i uniwersalny charakter wizji prawa naturalnego Tomasza z Akwinu jako źródła praw człowieka. Podkreśla, że w doświadczeniu siebie samego przez człowieka można odczytać zarówno prawdę o tym prawie, jaki i o ludzkich uprawnieniach. Dzięki temu koncepcja ta brzmi przekonująco i jest zrozumiała dla każdego człowieka, niezależnie od kontekstu czasowego, kulturowego i światopoglądowego. Dla Walda, podobnie jak dla Mieczysława A. Krąpca, podmiotem praw jest każdy człowiek ze względu na swą osobową godność rozumianą w sposób klasyczny, czyli mającą swe uzasadnienie w naturze ludzkiej, a nie w samych jej przymiotach. W swej prezentacji stanowiska niemieckiego myśliciela autor artykułu uwyraźnia i uszczegóławia niektóre wątki: definiowania prawa naturalnego jako źródła praw człowieka i doświadczania siebie samego przez człowieka we wszystkich rozpatrywanych aspektach oraz ukazania godności osobowej jako fundamentu praw.

\section{Summary}

\section{The natural law and human rights: the position of Berthold Wald}

\section{Keywords}

philosophy; natural law; human rights; person; human dignity; Thomas Aquinas; Berthold Wald 
The article presents Berthold Wald's views on the foundations of human rights. The author shares the views of the German thinker that the basis of these laws is the natural law, which in modern culture is neglected, contributing to the errors of embodying human dignity and freedom. Wald, in the author's view, in an original way shows the rational and universal nature of the vision of the natural law of Thomas Aquinas as a source of human rights. He emphasizes that in the experience of one's self you can read both the truth about this law and human rights. This makes this concept sound convincing and understandable for everyone, regardless of their temporal, cultural or philosophical background. For Walt, as for Mieczysław A. Krąpiec, the subject of rights is every human being because of his personal dignity, understood in a classical way, that is justified in human nature and not in its own qualities. In his presentation of the position of the German thinker, the author of the article exposes and delineates certain themes: defining natural law as a source of human rights and experiencing one's own self in all aspects concerned and showing the dignity of the person as the foundation of rights. 